\title{
Can the Hypnotized Subaltern Speak? Assessing 19th Century Gujarati Travelogues to England
}

\author{
Dhwani Vaishnav \\ Assistant Professor, Shantilal Shah Engineering College, Bhavnagar, Gujarat. Orcid Id: \\ oooo-ooo2-9528-7934.Email: dnv_o7_eng@yahoo.co.in
}

\begin{abstract}
Travel broadens the mind but it would be interesting to trace how many people actually have the opportunity to travel and learn something new. Even if travel is one of the most natural human instincts, written expression of travel experiences, i.e., travelogue is considered as a minor genre of literature. It is only in the latter half of the $20^{\text {th }}$ century that this genre gained popularity within literary circles. Indian travel writing and specially Gujarati travelogues started being written in the $19^{\text {th }}$ century, an age of social reformation in India. This paper endeavours to study three early Gujarati travelogues about journeys to England made by Mahipatram Rupram Nilkanth, Karasandas Mulji (both written in Gujarati) and Behramji Malabari (written in English) as representative writing depicting how Indians were influenced by the English and took note of English life during the age of colonialism. Mahipatram and Mulji faced uproar from their community but ventured to visit the land of the masters. Malabari as a student of humanity, went to search the truths of life, especially the study of human progress in two different civilizations by travelling and adopting a comparative method for which he thought a metropolis like London was the best place. The age of social reformation had already injected sparks of bringing change in these travellers. The grandeur of the English land hypnotized these subalterns. Hence, Mahipatram and Karsandas have tried to present a beautiful picture of the places whereas Malabari does not make any exception in his criticism about the life and culture of England. This paper analyzes the experiences of these three travels which were made between 1860 and 1890 and show how these travellers perceived the function of the British Raj in India and actually in their own land. Their awe, pleasure and dislike about a culture and a nation that was governing their own land for a long time would also be highlighted.
\end{abstract}

Keywords: travel, social reformation, colonialism, subaltern, Gujarati travelogue

Life, as the most ancient of all metaphors insists, is a journey; and the travel book, in its deceptive simulation if the journey's fits and starts, rehearses life's own fragmentation. -Jonathan Raban

Humans have travelled for various purposes like religious visits, commerce, education, migration and rehabilitation in his own country and in foreign lands. Travel for pleasure comes quite later with the modern developments and facilities. In a country like India, the metaphor of travel is attributed to everything including journey of ideas, life and death. In this sense, any journey can be constructed as a travel narrative. Ancient Indian writers like Ved Vyasa, Valmiki and Kalidas must have been passionate travellers. Their narrations capture picturesque view of pan-India which clearly exhibit that the idea of travel has always fascinated the Indian imagination as a path of learning and cultural construct. It is evident from the accounts of places and people in folk narratives, epics, chronicles and plays. In the modern context, travelogue, like the novel, is often

(C) AesthetixMS 2020. This Open Access article is published under a Creative Commons Attribution Non-Commercial 4.o International License (http://creativecommons.org/licenses/by-nc/4.o/), which permits non-commercial re-use, distribution, and reproduction in any medium, provided the original work is properly cited. For citation use the DOI. For commercial re-use, please contact editor@rupkatha.com. 
considered to be the product of the colonial encounter. However, one can even trace elements of travel writing in pre-colonial times.

Travellers have undertaken journeys and jotted down their experiences, and in the times of no printing facility, recorded their experiences in letter or diary form. With the development of the printing press and industry, circulation and approach of such writings became possible in foreign countries. By the time travel became a necessity in India, Europe had already few eminent travellers who produced remarkable output of their travel experiences. For India, travel became an important need in the colonial times because the British administration started sending people as slaves and workers to their other colonies. During this time, travel was taken within and outside the country by people like Mahipatram Rupram Nilkanth, Karsandas Mulji, Behramji Malabari, Dadabhai Navroji, Raja Ram Mohan Roy, Rabindranath Tagore, Gandhiji, Swami Vivekananda and Sankracharya to name a few, who also brought reform in India. Also some educated and upper middle class Indians felt a visit to Europe was necessary to know their country and learn their tradition and values to fight against the Raj in India. Such a thought promoted an idea of travel overseas for few reformers from various parts of the country.

The ban on foreign travel was not a traditional Indian phenomenon. During the medieval period, the decadent, ritualistic exclusivist culture of untouchability within and outside India and then invasions from foreign travellers tightened its hold on the minds of the people. But by the end of the nineteenth century, Indian travelogue seems to have come of age. Almost around the same time travel writing emerged as a major literary genre in the modern languages of India. Probably this was the product of a literary historical conjuncture: the colonial encounter that promoted English education and through it acquaintance with Western models. Moreover, the Parsi community availed themselves of the opportunities that came their ways in the form of new education or English language which became one of the most basic requirements for transaction with the new colonial rulers. Also, there was no prohibition or communal sanction against foreign travel, so they were among the first ones to travel and write travelogues in Gujarati. Hence Dosabhai Feramji Karaka published his Great Vritanni Musafir in 1861.

In the nineteenth century, Indian travel writing became popular due to certain specific reasons. They were namely, the emergence of a public sphere and an elite that could afford to travel, read and write; the maturing of prose in the language; intense translation activity; the birth of literary magazines; the greater mobility provided to the people by sudden improvement of facilities of travel like the introduction of railways and modern land and water transport systems; the coming into being of a class of colonial intellectuals who needed to travel for education and employment to the newly developed cities of India or at times of England; and pilgrimages to holy places. On the whole, there was a whole mobile middle class behind this sudden quickening of the travel nerve and the popularity of the genre in the languages of India. A spirit of reformation was prevailing in parts of the country and travel was becoming means for its spread. Gujarat participated in the reformation movement mainly through its contributions in politics and trade and commerce amongst other activities.

Although Gujarat did not resist colonialism politically through violence until Gandhi came to the front, it displayed penetrating insights in the areas of trade and commerce. People like Narmadashankar Lalshankar Dave, popularly known as Narmad, and Dalpatram Dahyabhai Travadi had welcomed British rule and modern developments in their literary works. People like Mahipatram Rupram Nilkanth (1829-1891) and Karsandas Mulji (1832-1871) were the initiators of journeys abroad. Since Gujarat then fell under the Bombay Presidency, the origins of its reform movements were interlinked with the reform movements in Maharashtra. Hence though neither 
Mahipatram nor Mulji was born in Mumbai, the shift from the native towns to an emerging city and the consequent inclusion in a reformist group were important factors governing their travel. Behramji Malbari (1853 - 1912) was already an established reformist of his age. For each of them their journey to England was a pilgrimage, a journey to pay homage to the source of reform and modern civilization because for none of them, the British presence in India had been a source of great unease. Mahiptaram was in the employment of the colonial government, whereas Mulji and Behramji Malabari drew from the British presence and social practices certain validity for the reform agenda. So, none of them took the opposition from their community for the journey overseas, either seriously or as an obstacle.

\section{I}

In 1860, Mahipatram Rupram Nilkanth travelled to England, amidst much rancour caused by his caste council of Nagar Brahmins. As the first travelogue in Gujarati literature, Englandni Musafarinu Varnan(1862) described contemporary political, social, and educational condition of England as well as descriptions of some popular places there. Nilkanth was an educationist and was sent to England by the government and his travel was paid by the English Company. Two colonial officers had also extended monetary help for his visit, the main purpose of which was to gain first-hand experience of the English education system. Due to this visit, Mahipatram would be helpful to the government in setting up teacher training colleges for natives. During his visit, Mahipatram realized that life in England was structured around two basic principles of British polity: the Rule of Law and Equality before Law. For him, these two principles gave England its unique modernity and civility. In his narrative Mahipatram did not give details of every day social interactions, rather as Tridip Suhrud says, "he is found most comfortable describing structures, principles and institutions" (2008, p. 84). He did not overlook the life of the lower class but he was convinced of the superiority of the British in all aspects. He said that it was known to all that these people were ahead of everyone in terms of wealth, welfare, knowledge, industry, education, polity, commerce and agriculture. He overwhelmingly praised British industriousness and saw the middle class as a true representative of its national character. He also appreciated English royalty and the spirit of people to join the army voluntarily.

Talking about a few good qualities of England and Englishmen, Nilkanth praised food habits of people as very decent. He also admired the dressing sense and other skills of English women. He observed that English people were enthusiastic, workaholic and targeted long term benefits. They did not give up their efforts easily. He observed that Englishmen believed in imparting good education to their kids and did not bother much for their marriage. He also described the famous library of Oxford and its working style in detail. He was happy to see that such a well-known library allowed foreign visitors to enter and avail books for reading. Looking at this practice, he suggested that sons of rich people of India should visit England, study there and bring change in India as without English training, no bad habits of Indians can be erased.

Along with praise for England, Nilkanth did not underestimate everything Indian under the impact of the colonizers' splendid halo. So, when he lavishly spoke of good things of England, he wished such good institutes and attributes in his own country. He believed that the main remedy to bring fortune to India was to travel to Europe because travel impresses more than listening from others or reading from some sources. He remarked that he had visited England to observe their (Englishmen) good qualities to learn something better otherwise their bad characteristics were faced in India too. The purpose of his visit was to benefit his own people. Thus, Nilkanth's response became in a way a representative of the collective mental image of the 
colonized. What he saw and recorded became his aspirations for his own countrymen and society. Through his travelogue he proved that travel is one of the best instruments of education.

\section{II}

Karsandas Mulji, a Gujarati language journalist, writer and social reformer also had to face uproar of his Baniya community when he planned visit to England in 1863 . Born to a family belonging to the trading Kapol Caste of western India, his visit was primarily for business in connection with the cotton trade, but when he returned to India after being unsuccessful in that, he was excommunicated from his caste. In his preface to Mulji's travelogue, Englandma Pravas (1886), Bholabhai Patel informs us that the prohibition on travel by sea was applicable only to uppercaste Brahmins since fisherman, non-Brahmin Hindus and Parsis from Gujarat had been travelling to many parts of the world. Mulji travelled to England with the thought of gaining exposure of their world which would enable him to witness the culture and lifestyle of the powerful country. He thought that he would probably be able to bring in the same change in his country which might make India free from slavery and make her equally powerful. Mulji noted in his Preface why he wrote this book:

It is my earnest request that my countrymen should give a patient and careful perusal to the volume, which I will hope, create not only a desire to visit the great and glorious land of commerce, learning and benevolence, but the more important desire of raising themselves and their country to the same level. (qtd. in Patel, 2001, p. 25).

Mulji's text begins with an elaborate discussion on the advantages of travelling for cultural, political and economic reasons. Upon entering Europe, he found himself in some wonderland. Buildings were giant and life so fast, parks were beautiful and clean, museums were rich and people were caring, educated, adventures and industrious. The beauty and splendour of England were marked by Mulji's breathless amazement which betrayed an apolitical and uncritical attitude starkly different from his attitude towards his own community. He compared life of women in England and in India. He perceived that English women were different and better in their education, freedom and training whereas Indian women were entangled in the rigid traditions which made them double slaves. Mulji felt that Indian women did not get exposure of the outside world. He advised readers not to judge an Englishman by his behaviour in India, which he thought was an exception rather than the norm, because British politics was based on the idea of betterment of their countrymen. So the way a few Englishmen were ruling their colonies including India, were exceptions or they were strict out of compulsion. On the other hand, people in England wanted more exchange between the two countries to develop through more dialogue and commerce. Mulji did believe that commerce and industrial development between both the countries would improve the standard for India. His suggestions for earning through trade with colonial countries were his eulogistic attitude towards England. His stance in economic matters also spoke of the generally profitable equations of mercantile communities with colonialism. Mulji attempted a different strategy of subversion through economics and suggests new trade equations by which Indians could exploit the English market.

In his narrative Mulji described in detail each place in England which was worth seeing, exploring and learning. He minutely noted all the details of the place for his readers. He compared qualities of people that our people did not have, namely such abilities or skills like making landscape paintings or adventure and industriousness and the competitive instinct of the English working class. People in England were better placed so they had the capacity to buy different fashionable items of the time. He observed that parents spent a considerable amount for the education of their children. He believed that education, skill, inventions and art, industries, 
climate, spread of railway, use of common language, navy, and the concern of the government were the positive factors and reasons for growth of the country. He also reported that unlike India, people in England were not cheated in the name of religion.

Political awareness of a colonial construction is missing in Mulji's travelogue. Travel seems to have reinforced his notion that colonialism was not merely justifiable but it was fortunate. At some point in his travelogue Mulji wished that British governance should continue in India. He took this passage with a view that travel teaches and broadens the mind. He believed higher education was not complete without a visit to the free and civilized land of England. His attempt was to capture a true picture of the life of civilized people without neglecting the poor and the downtrodden. He showed remarkable attention towards each aspect of social life and drew a more real image of the English life. To lessen concern for food, he informed his Hindu readers the fact that one does not need to be a non-vegetarian to stay in England because that was one of the major obstacles for Hindus not travelling to a foreign land. His attempt was to teach his people about the futility of the taboos of travel overseas. Through this visit and his writing, Mulji wanted to break the rigidity of social evils of Indian society and lead his country towards all possible developments. The model for this development was England and he could not thus resist praising them consciously.

III

Behramji Malabari, the poet, publicist, author, and social reformer was best known for his ardent advocacy for the protection of the rights of women and for his activities against child marriage. His travel to England in 1890 was an attempt to establish a friendly dialogue with English council and also visit the land of freedom which had greater value than the land of his birth. In his travel narrative The Indian Eye on English Life or Rambles of a Pilgrim Reformer (1895), written in English, Malabari intended to compare two civilizations and human progress in those civilizations. After travelling extensively within India, he believed that a metropolis like London could give him more insights for his comparative study. For Malabari, London was not only a fascinating imperial theatre spatially, it also provided discursive space for contrast and comparisons with scenes in India and those in Europe, across which Malabari travelled later. This play of difference and similarity between the colonial periphery and the centre as nuanced by the third axis of continental European cities like Paris or Rome is present in many other travel texts of the age including Mulji's travelogue where India was compared twice with Paris and England. Unlike Mulji, Malabari did not find German-speaking passengers very agreeable on his boat journey. His initial days in London frustrated him. He felt need for order and quiet in the city. Malabari too took note of English women how they enjoyed dignity and freedom in England. He felt that women were a presence and a power in Europe. In Asia, a woman was a vague entity, absorbed in the shadow of artificial sexuality. He noted that the most striking quality of a woman in England was to look after her health, strength, and elasticity - all proclaiming a freedom of mind.

Like Mulji, Malabari also observed all the reasons for the growth of England but he felt that it was a kind of money-making tendency and mania for 'novelty' and excitement in the English mind which drew them more towards their developments. He criticized their food, drinking and smoking habits, considering them disagreeable. Malabari was scathing in his criticism in the lack of decorum and etiquette of the British crowd. He found the city too unwieldy, unorganized and artificial. He was perturbed by the lack of refinement of English manners especially when they were enjoying their holidays and outings. He praised the family system and motherhood that Indian women perform. For him the Indian family system was really 
admirable whereas English families did not bother much about this system. On the contrary, in the name of individual freedom, except for the middle class, they did not find marriage necessary.

Malabari also detailed that science worship was not appreciable as under the guise of which vivisection kills animals. He discussed various professionals; their routine and behaviour towards tourists which was remarkably polite most of the time, but he noted that in England also people cheat and take benefit of the opportunity. Christianity in England struck him as being concerned with the muscular principle, 'to aggrandize, to conquer and to rule'. There was a deep sadness that he experienced about the fate the teachings of Christ had met with in England. He felt that as people, Englishmen were not worthy of their ancient Christian heritage and remarked:

It is a life from which the divine has been eliminated, or in which, another dwelling place. It makes one wonder at such times if the life and teachings of Christ - Britain's most precious heritage - may not be thrown away upon people whose spiritual appreciation is so defective. (Malabari, p. 96).

Malabari hinted at the very heart of the colonial enterprise and rejected the British claim to present superior culture and a superior religion. It was a culture, which was governed by no ideal other than self-aggrandizement. He said, "If this be your culture of the nineteenth century, let us remain ignorant in India. I had much rather that India remained superstitious enough to worship her stone gods. The worship of the self is the worst form of idolatry." (Malabari, p. 75). He also considered England as 'an artificial civilization of the West' which was dominated by King Coal and Emperor Iron and typified as Kaliyuga by the wise men of the East. Its price was being paid everyday in disease and death; in accident and crime.

The thirty years that separate the travels of these three travellers amply clarify the distance traversed by the language of social reform. Nilkanth worked for the colonial government and he was primarily sent to England to scoop out ideas from England's institutions of higher learning. As he was overawed with the grandeur of the land, it was difficult for him to manage complete objectivity. Mulji wrote the account of his time in England in a less overwhelmed tone than Mahipatram. It is empirically factual and the description is multi-layered. As a bourgeois representative of a class of Indians who saw colonialism as benign education, Mulji's response to the country of his colonial masters made him gloss over the unethical nature of domination. On the other hand, Malabari succeeded in his pilgrimage as it was an endeavour towards selfdiscovery. By capturing the essence of modern England, he was able to reject the colonial cultural agenda. His narration is weighed on the scales of his own perception of an 'alien and yet familiar' - life as he saw it lived, not always and necessarily as it was lived. He was almost happy leaving behind this decaying civilization when he stated:

And now farewell to London! Dirty little pool! A life, that has grown and expanded into an ocean - the biggest, the muddiest and yet the healthiest of this Iron Age. (Malabari, p. 245).

As Rita Kothari mentions in her essay, the main impetus behind Nilkanth and Mulji's travelogues was "consistent with a larger project aimed at infusing rational progressive thought into Gujarati society” (Kothari, 2008. p. 92). However, Malabari's travelogue is an attempt of a colonized to seek 'to examine' and better understand, in his or her own terms, the colonizer.

Travelling is a kind of modernity because it aids and raises the individual and also the management of economic and cultural capital. A common man - a subaltern, who was twice suppressed under social and cultural colonization - did not have the luxury of education, travel, and have his say even in his own country. At least people like Mahipatram, Mulji and Malabari 
could travel and they tried to bring the real picture of the England to their homeland. Mahipatram and Mulji were fascinated by England at the first sight, especially with her imposing architecture, novelty and freedom of the land which was natural for a traveller travelling in any better developed civilization. But at the same time they developed a blinkered vision of the way the British Raj in India functioned.

Like many of his contemporary writers and reformers, Mahipatram had seen English rule as an avenue to bring about reformation from social evils. But his admiration for English society did not disturb his sense of judgement as he also mentioned drawbacks of the English society. He praised his visit to Paris and while comparing both cultures, he did not miss to mention the humiliation he underwent at an English railway station where people did not want to share the coach with him. He realized that it was arrogance of the person who believed that those who are being ruled by his country should not have privilege of sharing the same compartment. In the second chapter of his narrative he mentioned that there were many thieves, cunning men and immoral women (in London). His hatred for the perverted Englishmen in India was the permanent mood as he had noted it with an illustration conveying the disapproval of the uncivil behaviour of an Englishman spoiled in India. Nilkanth's travelogue thus becomes a description of the encounter between the loyal colonized subject and the imperial colonizer. However, his journey turned out to be a learning experience at the individual level and a culturally enriching activity at the larger level. Malabari severely criticized the weakness of the foreign land and appreciated India for few of its cultural and social peculiarities. Even if amazed by England, Mahipatram and Mulji offered their experiences in writing which provided substantially clear picture of the Indian rulers. And Malabari could get a newer comparative vision due to different cultural and social realizations in a foreign land. Their endeavour put them, subaltern otherwise, in the list of social reformers who became modern with their travelling to Europe.

These three early Gujarati travelogues bring into focus the ambivalences in the social reform movement and the point to its entrenchment in the upper-caste sections of the Gujarati society. The adjective sudhrela which literally means 'improved' or 'corrected' was used by the colonized, including the nineteenth century social reformers, for the advanced or developed nations. Gradually, the lower castes began to refer to the upper castes as sudhrela, making the term embrace Brahminisation and Westernisation. The new sense of self as something apart and distinct from a group can be seen as an extension of colonial modernity. The taboo on travelling as well as the privilege of travel exposure and learning were applicable only to the upper castes. Therefore, the taboo regarding travel, despite being based upon the ideology of pollution that was the cornerstone of the caste system did not impinge upon the caste structure. Thus, while undertaking their travel, these travellers showed exceptional courage to go against their communities. Both Mahipatram and Mulji were ostracized and Mulji had to die remaining out caste. Because socially they were slightly in a better position, they used travel as a tool for studying another civilization and culture that has been ruling their own land so powerfully and successfully.

Thus, though these early travel narratives might not be interesting in their manner of narration or excellent in providing details, they still have great significance. The efforts of these three reformist travellers gave a scope to their countrymen to be familiar with the colonizers and the reasons of their greatness and weaknesses which could be addressed in their own land. Hence, though hypnotized, Mahipatram and Mulji tried to educate and familiarize themselves with England and Malabari could bring out effective comparisons putting India on a higher pedestal. A 
hitherto marginalized and minor genre of literature - travelogue - has thus become very important historical document revealing the function of the British rule in two different lands.

\section{References}

Baxi, A. (1984). Gujarati Pravassahitya. Vallabhvidyanagar: Sardar Patel University Press.

Bhattacharji, S. (Ed.). (2008). Travel Writing in India. New Delhi: Sahitya Akademi.

Kothari, R. (2008). Crossing the Sea: Nineteenth Century Travelogues in Gujarat. in Shobhana Bhattacharji (Ed.), Travel Writing in India, (pp. 92-102). New Delhi: Sahitya Akademi.

Malabari, B. (1895). The Indian Eye on English Life or Rambles of a Pilgrim Reformer ( $3^{\text {rd }}$ ed.). [eBook edition]. Apollo Printing Works. https://archive.org/details/indianeyeonenglioomalarich accessed on 1oth January, 2015.

Mulji, K. (1886). Englandma Pravas. (rpt. 2001)(Patel, Bholabhai \& R.L. Raval. Eds.). Gandhinagar: Gujarat Sahitya Academi.

Neelkanth, M. R. (1862). Englandni Musafarinu Varnan ((Rpt. $19986^{\text {th }}$ ed.). Ed. Bholabhai Patel. Gandhinagar: Gujarati Sahitya Parishad.

Suhrud, T. (2008). Indian Eyes on English Life in Shobhana Bhattacharjee (Ed.), Travel Writing in India, (pp. 84-92). New Delhi: Sahitya Akademi. https://libquotes.com/jonathan-raban/quote/lby8v5z accessed on 15th April, 2020. 